
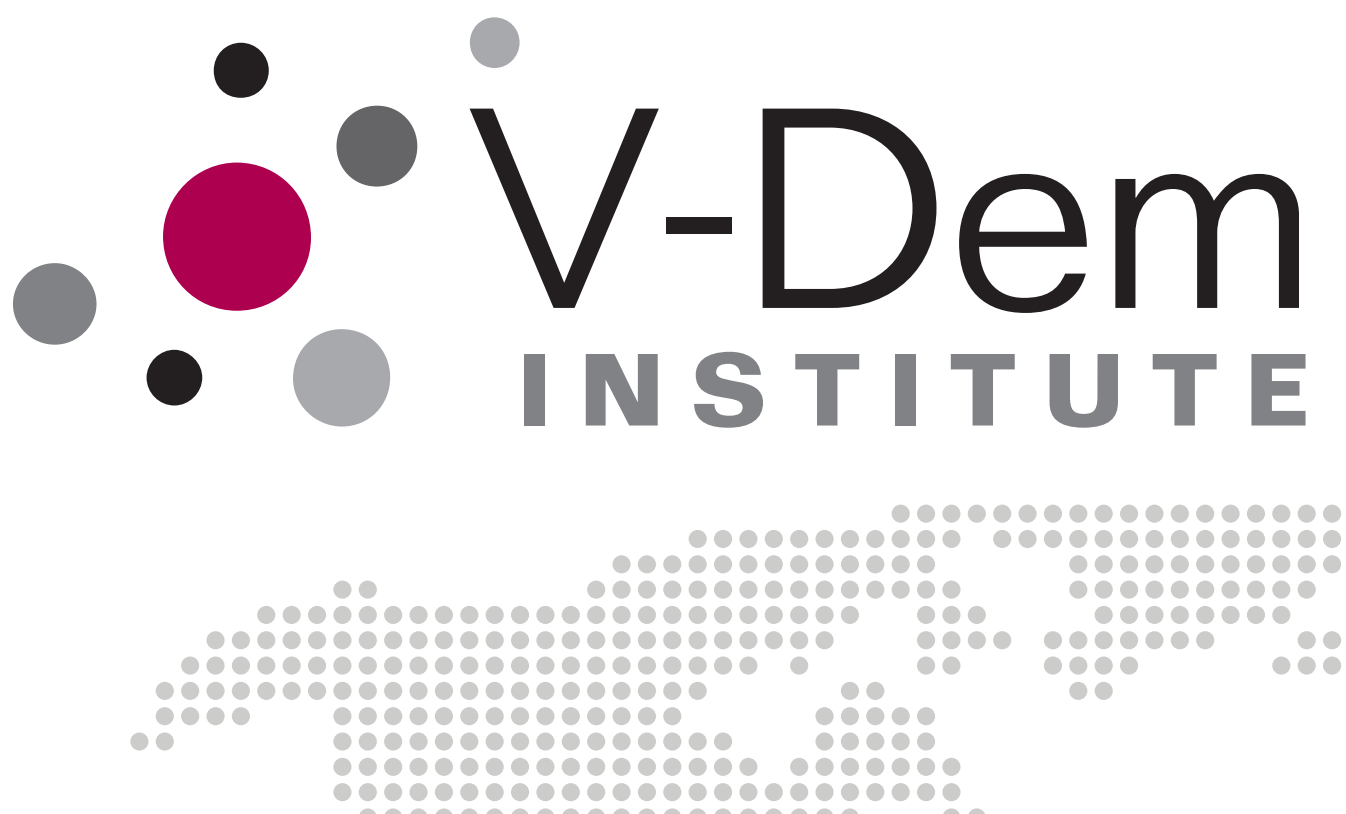

Party Organizations Around the Globe. Introducing the Varieties of Party Identity and Organization Dataset (V-Party)

Nils Düpont, Yaman Berker Kavasoglu, Anna Lührmann, Ora John Reuter

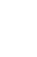

00000

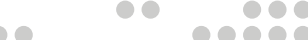
00000000 00000000 00000000000000000 O

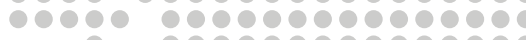
00000000000000000

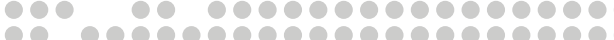

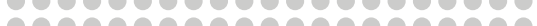

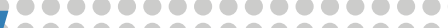

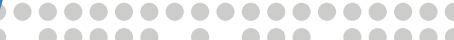

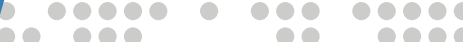
60

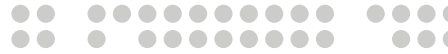

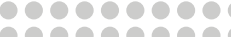
1

100000000

0000000000000

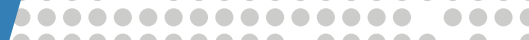

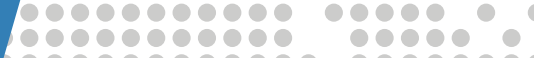

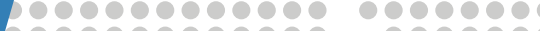

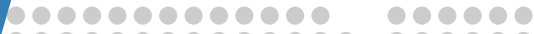

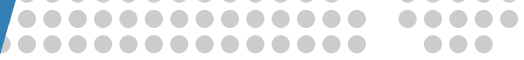
1000000000000000 00000000000000000000

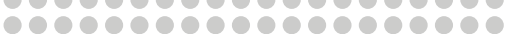

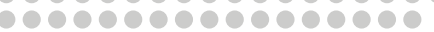
○०००००00000000

0000000000000

00000000000

00000000000

1000000000 00000000000

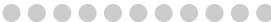
00000000000

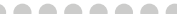
000000000 1000000

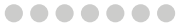
000000

00000000

0009000

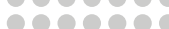



000

rópos

1000

000

0

100

10

○ी 0

8

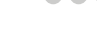


Varieties of Democracy (V-Dem) is a new approach to conceptualization and measurement of democracy. The headquarters - the V-Dem Institute - is based at the University of Gothenburg with 23 staff. The project includes a worldwide team with 5 Principal Investigators, 19 Project Managers, 33 Regional Managers, 134 Country Coordinators, Research Assistants, and 3,500 Country Experts. The V-Dem project is one of the largest ever social science research-oriented data collection programs.

Please address comments and/or queries for information to:

\author{
V-Dem Institute \\ Department of Political Science \\ University of Gothenburg \\ Sprängkullsgatan 19, Box 711 \\ 40530 Gothenburg \\ Sweden \\ E-mail: contact@,v-dem.net
}

V-Dem Working Papers are available in electronic format at www.v-dem.net.

Copyright (C2021 by authors. All rights reserved. 


\title{
Party Organizations Around the Globe. Introducing the Varieties of Party Identity and Organization Dataset (V-Party). ${ }^{*}$
}

\author{
Nils Düpont \\ Postdoctoral Researcher \\ CRC 1342 "Global Dynamics of Social Policy" \\ University of Bremen \\ Yaman Berker Kavasoglu \\ Doctoral Research Fellow, V-Dem Institute \\ University of Gothenburg \\ Anna Lührmann \\ Assistant Professor of Political Science \\ University of Gothenburg \\ Ora John Reuter \\ Associate Professor of Political Science \\ University of Wisconsin-Milwaukee
}

\footnotetext{
* This research project was supported by the Swedish Research Council [Vetenskapsrådet] [grant number 2018-016114], PI: Anna Lührmann and European Research Council [H2020 European Research Council], grant 724191, PI: Staffan I. Lindberg, V-Dem Institute, University of Gothenburg, Sweden as well as by internal grants from the Office of the ViceChancellor, the Dean of the Department of Social Sciences, and the Department of Political Science at the University of Gothenburg. Nils Düpont appreciates funding from the German Research Foundation [Deutsche Forschungsgemeinschaft] via Collaborative Research Center [SFB] 1342 "Global Dynamics of Social Policy" at the University of Bremen.
} 


\begin{abstract}
Although party organization plays a key role in a range of theories from democratic accountability and representation to democratic breakdown or the electoral success and persistence of parties, data on party organizational features is quite sparse, scattered and available for a limited set of countries and parties. To advance global research on party organizations, we present the Varieties of Party Identity and Organization Dataset (V-Party) - the most comprehensive dataset to date, including a wide range of information about organizational features and party stances of more than 1,900 parties in 168 countries between 1970 and 2019. Here, we focus on new measures of parties' territorial reach, ties to social organizations, candidate nomination procedures, personalization, and internal cohesion. Focusing on the organizational features of political parties, we demonstrate the usefulness and the potential of VParty following Adcock and Collier's (2001) three-pronged strategy to showcase V-Party's face, criterion and construct validity.
\end{abstract}




\section{Introduction}

The organizational makeup of political parties has crucial implications for some of the biggest questions in comparative politics. Research suggests that party organizational characteristics are consequential for electoral success and the durability of political parties (Bolleyer, Correa, \& Katz, 2019; Tavits, 2012; Wills-Otero, 2016) which is key to ensure the accountability of elected leaders essential for democratic survival (Bernhard, Hicken, Reenock, \& Lindberg, 2020). Furthermore, party organizational features help explain public spending (Rasmussen \& Knutsen, 2019), political corruption (Schleiter \& Voznaya, 2018), or economic growth (Bizzarro et al., 2018). In autocratic settings, ruling party organizational features are key predictors of autocratic regime durability and transition to democracy (Kavasoglu, 2021; Levitsky \& Way, 2010; Reuter, 2021).

Although party organizations feature prominently in explanations of substantive political outcomes, research is often hindered by a lack of data on party organizational features. Despite some notable recent contributions (e.g. Kitschelt, 2013; Poguntke et al., 2016), existing data sets on the party level are limited to a small number of cases from specific geographical regions, typically have limited time coverage or cross-sectional structures, thereby constraining researchers' ability to examine the causes and effects of party organizational features over time.

To advance comparative research on party organizations, we present the Varieties of Party Identity and Organization Dataset (V-Party) - the most comprehensive publicly available dataset to date, including a wide range of information about organizational features and party stances of more than 1,900 parties in 168 countries between 1970 and 2019. In this article, we introduce V-Party's measures of parties' territorial reach, ties to social organizations, candidate nomination procedures, personalization, and internal cohesion (see Lührmann, Medzihorsky, \& Lindberg, 2021 who present some of VParty's measures of party identity).

In the following sections, we briefly introduce V-Party and its (methodological) foundation, and we provide some first, descriptive impressions (2). We then follow Adcock and Collier's (2001) threepronged strategy to assess the validity of the party organizational data. First, we look at face or content validity by investigating to what extent descriptive data patterns match our expectations about single parties (3.1). Second, for criterion or convergent validity we compare the new data to extant data measuring similar concepts (3.2). Finally, for construct or nomological validity we re-evaluate a wellestablished hypothesis about the party organizational features-electoral persistence nexus (3.3). Presenting and utilizing V-Party's new measures of party organization, we thus pave the way for (re-) assessing some of the most pressing questions in comparative politics - for the first time from a global perspective. 


\section{Measuring Party Organizational Features - The V-Party Survey}

V-Party offers key information on political parties combined with comprehensive expert-coded assessments. Building on the infrastructure of the V-Dem Project and Institute (Coppedge, Gerring, Knutsen, Lindberg, Teorell, Alizada, et al., 2020) and jointly utilizing Party Facts and Elections Global (Döring \& Düpont, 2020; Döring \& Regel, 2019), the V-Party project compiled basic information on virtually all political parties represented in parliaments, their vote and seat share for all V-Dem countries during the period 1900-2019 (see Lührmann et al., 2020). For the time period 1970-2019, V-Party additionally offers expert-coded assessments of party organization and identity for 1,941 parties across 1,755 elections in 168 countries, or 6,313 party-election year units in total. Using V-Dem methodology (Coppedge, Gerring, Knutsen, Lindberg, Teorell, Marquardt, et al., 2020), in January 2020665 experts rated the policy positions and organizational capacity of political parties in a given country for all parties that reached more than $5 \%$ of the vote share at a given election. The questionnaire was developed in a series of consultative meetings between 2017 and 2019 and tested in a pilot study in summer 2019. The coding was conducted in early 2020. It was then aggregated using V-Dem's Bayesian Item Response Theory measurement model (Pemstein et al., 2019). Typically, at least 4 coders provided their assessment per observation.

Beyond policy stances, V-Party includes several items that capture different aspects of party organizations (Lührmann et al., 2020). Table 1 lists six items, their question wordings and response categories that are particularly useful for assessing party organizational features.

For one, V-Party includes measures of organizational extensiveness, pertaining to a party's capacity to reach and mobilize supporters across local communities which is at the core of classical accounts of party organizations (e.g. Duverger, [1951] 1981; Janda, 1980; Kirchheimer, 1965; Michels, [1911] 1962; Panebianco, 1988). The measures focus on three attributes related to party organizational extensiveness: (1) geographic breadth of organization, (2) the depth of grassroots organization at the local level, and (3) links to social organizations. The first attribute refers to parties' territorial organization in terms of the presence of permanent local branches across municipalities, while the second attribute refers to widespread active presence of personnel and party activists across local communities. Finally, the third component of organizational extensiveness captures the strength of parties' ties to civil society organizations (Kitschelt, 1994). 
Table 1 V-Party Items for Measuring Party Organizational Attributes

Item

Question

Does this part

Local party

offices

(v2palocoff) operate outside of election campaigns at the local fices.

or municipal-level?

Active commu-

nity presence

(v2paactcom)

Affiliate organizations (v2pasoctie)

Candidate nomination (v2panom)

Elite

cohesion

(v2padisa)

Personalization of party (v2paind)
To what extent does this party maintain ties to prominent social organizations?

Which of the following options best describes the process by which the party decides on candidates for the national legislative elections?

To what extent do the elites in this party display disagreement over party strategies?
...

To what degree are party activists and personnel ties.

... ties.

...

...

...

...

\section{Response categories}

0 : The party does not have permanent local of-

4: The party has permanent local offices in all or almost all municipalities. 0 : There is negligible permanent presence of party activists and personnel in local communi-

4: There is widespread permanent presence of party activists and personnel in local communi-

0 : The party does not maintain ties to any prominent social organization.

4: The party controls prominent social organizations.

0 : The party leader unilaterally decides on which candidates will run for the party in national legislative elections.

4: All registered voters decide on which candidates will run for the party in national legislative elections in primaries/caucuses.

0 : Party elites display almost complete disagreement over party strategies and many party elites have left the party.

4: Party elites display virtually no visible disagreement over party strategies.

0 : The party is not focused on the personal will and priorities of one individual leader.

4: The party is solely focused on the personal will and priorities of one individual party leader.

V-Party also includes measures that capture the distribution of decision-making authority within parties. While some parties allocate more decision-making powers to the individual party leader or a small circle of elites, others disperse authority among groups organized at various layers within the organization. The degree to which lower cadres and members are active in internal politics has important implications for organizational goals, party policies and campaigning (Katz \& Mair, 1994; Levitsky, 2001; Panebianco, 1988; Schumacher, Vries, \& Vis, 2013). Accordingly, V-Party's first item refers to the internal balance of power between different organizational levels over the selection of party's legislative candidates. This indicator recognizes the fact that in many parties candidate nomination procedures vary across constituencies, and party leaders often sidestep lower cadres and 
nominate their preferred candidates even where de jure rules dictate otherwise (Ichino \& Nathan, 2012). Conversely, the second item denotes party personalization which refers to the degree to which an individual party leader dominates internal decision-making without facing effective constraints.

Finally, V-Party captures elite cohesion within parties reflecting what Janda (1980, p. 118) called "the degree of congruence in the attitudes and behavior" (see also Hazan, 2003 for a conceptual discussion). Parties vary in the extent to which they are able to quell internal conflict. Especially in democracies, "[c]ohesion and discipline matter in the daily running of parliaments" (Bowler, Farrell, \& Katz, 1999, p. 3) and cohesion has been linked, for example, to legislative behavior (Hix, 2001), the functioning of (coalition) governments (Druckman, 1996; Giannetti \& Benoit, 2009), and to factionalism (Boucek, 2009). Meanwhile, in autocracies elite cohesion has been linked to regime survival (e.g. Brownlee, 2007; Levitsky \& Way, 2010).

In the following, we exclude closed autocracies (Lührmann, Tannenberg, \& Lindberg, 2018) where the executive branch is not subject to elections. To facilitate our validation exercise, we aggregate the items into three scales. Entering all six items into an exploratory factor analysis (EFA), an appropriate tool for uncovering latent dimensions (Comrey \& Lee, 1992), revealed three distinct factors:

(1) Permanent local party offices ( $v 2$ palocoff), active local community presence ( $v 2$ paactcom), and ties to social organizations (v2pasoctie) always load high on one factor. This dimension captures organizational extensiveness, with high levels indicating a party with extensive grassroots organization.

(2) Personalization (v2paind) and candidate selection (v2panom) always constitute a second factor. When switching the scale of $v 2$ paind both items pick up the intra-party power concentration between the "party on the ground" (Katz \& Mair, 1993, p. 597) and the leadership, with low levels indicating parties with a hierarchical structure where power rests in the hand of one leader or just few momentous party elites.

(3) Finally, elite cohesion (v2padisa) most often embodies a third factor. This is line with Tavits (2011), LeBas (2011) and Levitsky and Way's (2010) notion that cohesion represents a distinct dimension of party organizations.

Based on the EFA, we build two indices capturing organizational extensiveness and intra-party concentration, treating elite cohesion as a separate dimension. For our purposes, we opt for additive indices applying no weights and using the standardized items which allows for partial substitutability among the components of organizational extensiveness and of intra-party power concentration. Table 2 shows descriptive statistics for single indicators and the three dimensions. Alternative specifications of the EFA and additional descriptive statistics for each item can be found in the Online Supplement. 
Table 2 Descriptive Statistics for Party Organizational Items and Dimensions

\begin{tabular}{lcccccc} 
Item/Dimension & $\mathbf{n}$ & mean & sd & min & median & max \\
\hline Local party offices (v2palocoff) & 4250 & 0.48 & 1.38 & -3.14 & 0.60 & 3.23 \\
Active community presence (v2paactcom) & 4225 & 0.42 & 1.34 & -3.04 & 0.47 & 3.67 \\
Affiliate organizations (v2pasoctie) & 4147 & 0.03 & 1.28 & -3.55 & -0.02 & 3.93 \\
Candidate nomination (v2panom) & 4030 & 0.22 & 1.33 & -3.32 & 0.23 & 4.66 \\
Elite cohesion (v2padisa) & 4218 & 0.07 & 1.22 & -4.46 & 0.08 & 3.02 \\
Personalization of party (v2paind) & 4280 & -0.17 & 1.40 & -2.93 & -0.23 & 3.92 \\
Organizational extensiveness & 4131 & -0.05 & 2.55 & -7.43 & 0.03 & 6.65 \\
Intra-party power concentration & 4015 & 0.03 & 1.77 & -5.30 & 0.16 & 3.98 \\
Elite cohesion & 4218 & -0.05 & 0.99 & -3.72 & -0.04 & 2.34 \\
\hline
\end{tabular}

\subsection{Trends and Descriptive Insights}

To provide some insights, Figure 1 displays global trends for each dimension split by regime type (Lührmann et al., 2018). ${ }^{1}$ Given our global sample, Figure 1 demonstrates that the "party on the ground" (Katz \& Mair, 1993, p. 597) in liberal democracies is becoming slightly less grounded, corroborating Dalton and Wattenberg's (2000) discussion. Regarding intra-party power concentration, we see an expected ordering with parties in electoral autocracies being more centralized and hierarchical while parties in liberal democracies give lower cadres relatively more say in decision-making. However, for liberal democracies there is also evidence of increasing concentration of power in the hands of an individual party leader or a small circle of party elites supporting Blondel et al.'s (2010) and Poguntke and Webb's (2007) findings about a growing personalization or "presidentialization" of party politics in the recent past. In addition, political parties in many countries that joined the club of liberal democracies during the 1990s and 2000s (foremost post-communist countries in Eastern Europe, and several Latin American countries) tend to be less extensive, more centralized and dominated by individual party leaders than most party organizations in Western Europe (cf. Online Supplement). The notable decline in organizational extensiveness and elite cohesion and the increase in intra-party power concentration towards more inclusive parties is to a large extent indeed attributable to the collapse of communist single-party regimes (cf. also Figure 2).

\footnotetext{
${ }^{1}$ In the Online Supplement we provide additional plots and descriptive statistics from which we draw in the text.
} 
Figure 1 Global Trends of Party-Organizational Features, 1970-2019
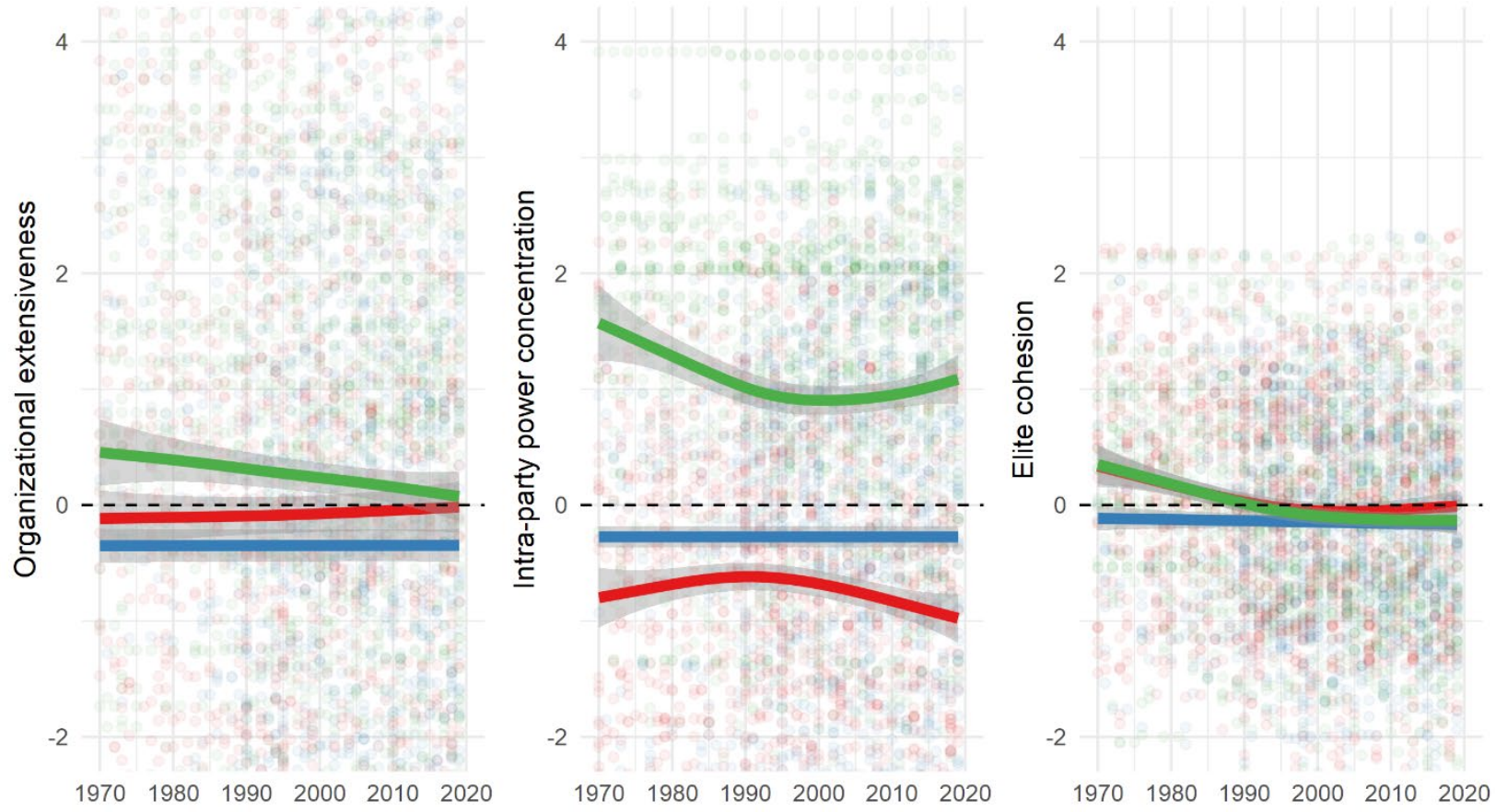

Regimes of the World (RoW)

Electoral autocracy

Electoral democracy

Liberal democracy

In recent years, there is negligible difference in party cohesiveness between electoral autocracies, electoral and liberal democracies reflecting Olson's (2003) reasoning that regime factors are insufficient for explaining the variance among parties. It is notable, however, that parties in liberal democracies became increasingly less cohesive, likely because in many relatively young liberal democracies politicians have weakly developed party loyalties that are fundamental to intra-party cohesion (e.g. Mainwaring \& Linan, 1997).

Turning to the overall distribution and development of the three dimensions over time across different socio-political regions, we highlight some notable patterns (see Figure 2). To start with, the data indicates that, on average, parties in Western Europe and North America display higher levels of organizational extensiveness, and tend to give the lower cadres higher degree of influence in internal decision-making than their counterparts in other regions. The right-skewed distribution, the narrow confidence interval, and relatively little change over time corroborate Poguntke et al.'s $(2016,668)$ finding of "the sheer uniformity in basic organizational structures and rules" [emphasis in original] in Western democracies where "[b]oth old and new parties adhere to a subscriber democracy organizational model in which dues-paying members are the polis for most or all important decisions". 
Figure 2 Regional Variation and Trends of Party Organizational Features, 1970-2019
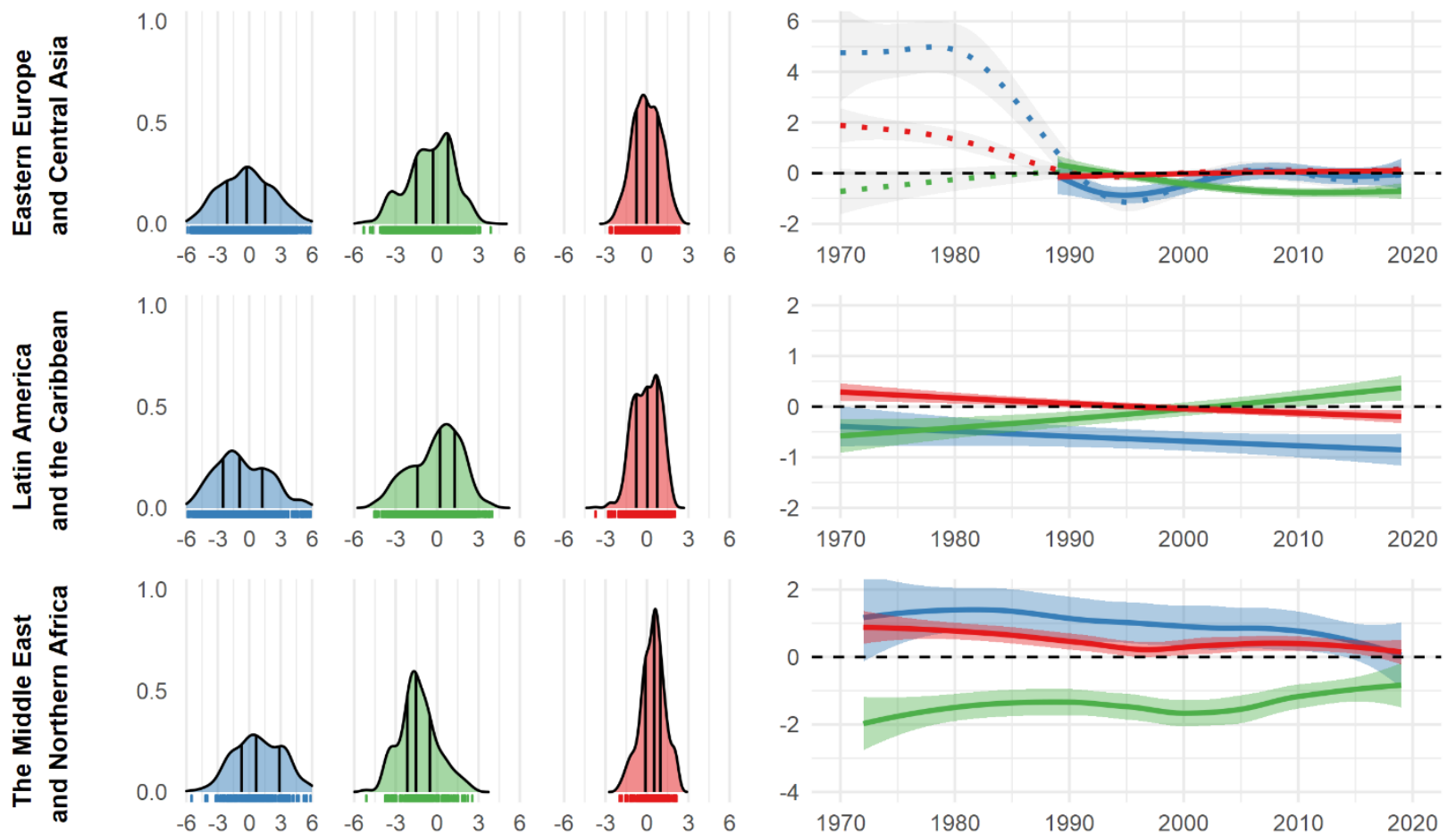

帒

1.0
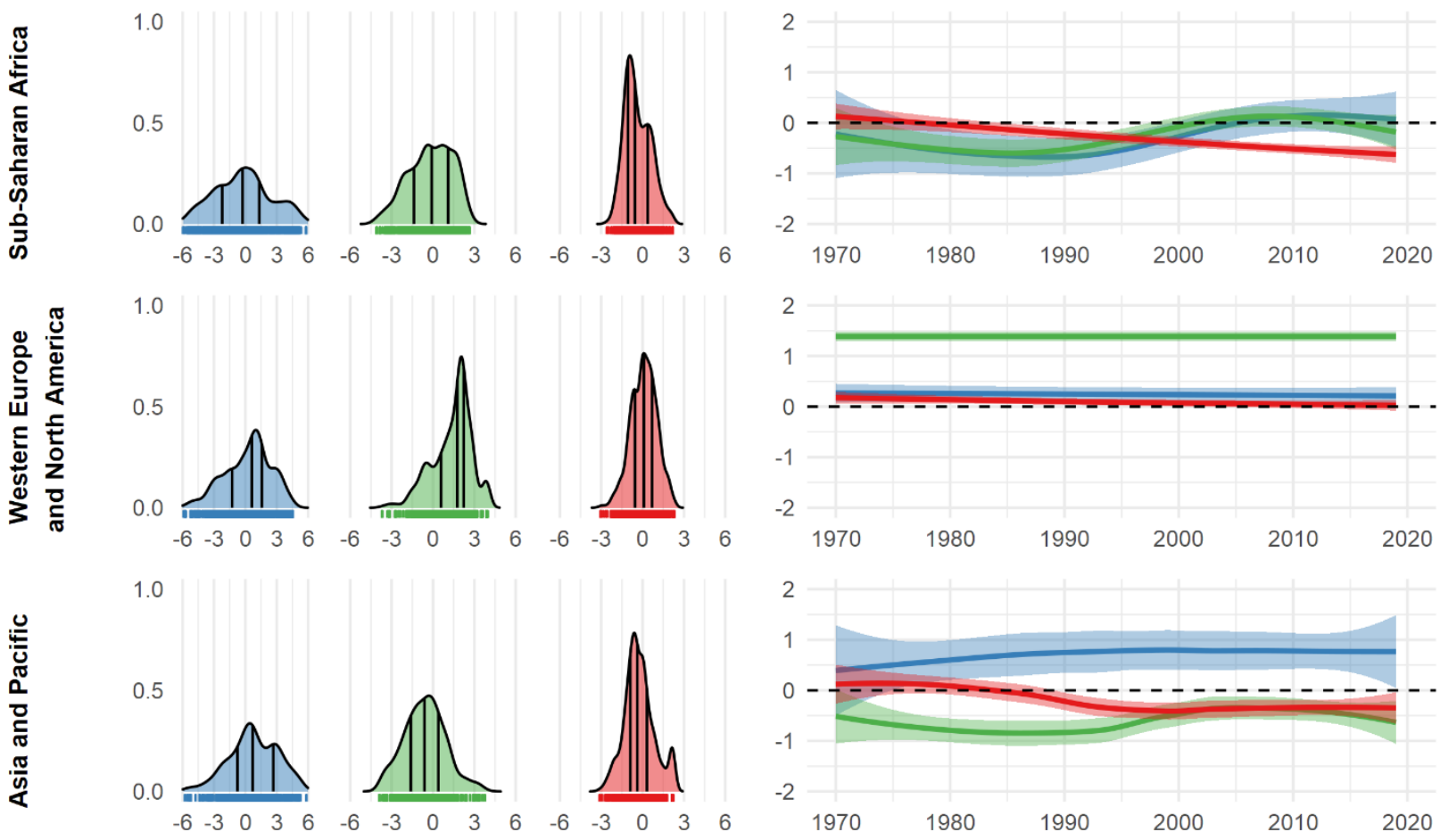

- Organizational extensiveness

- Intra-party power concentration

- Elite cohesion

Note: To the left are density plots with horizontal lines representing $25 \%, 50 \%$ and $75 \%$ quantiles; plots to the right show smoothed conditional means over time with $95 \%$ confidence intervals; for illustrative purposes, the dotted lines for Eastern Europe and Central Asia include data on closed autocracies, foremost the communist single-party regimes. 
Looking at Africa, the wide dispersion of party organizational extensiveness confirms Elischer's (2013) observation that there is substantial variation in organizational features of African parties. In line with existing research, V-Party data also shows that parties in sub-Saharan Africa are organizationally less extensive than parties in other regions, but there is notable variation across parties in the region (most likely due to an incumbent-opposition party divide; Wahman, 2017). Moreover, we observe a notable increase in party organizational extensiveness since the early 1990s - a period coinciding with the resurgence of multiparty elections in the region - which further explains recent findings about the gradual stabilization of African party systems (Weghorst \& Bernhard, 2014). In a typical African party system, presidentialism and historical legacies favor personalistic parties and limited decentralization of candidate selection procedures (Lindberg, 2007), but as the distribution of intra-party power concentration index demonstrates not all parties in the region possess such organizational features (Elischer, 2013; Seeberg, Wahman, \& Skaaning, 2018).

For Latin America and the Caribbean, Coppedge (1998, p. 547) observed notable differences within and across countries. At one extreme are countries such as Peru and Guatemala where politicians have few incentives to invest in party-building (Levitsky \& Cameron, 2003; Nájera, 2010), and parties therefore rarely survive beyond an election. At the other extreme, countries such as Chile and Mexico have parties with relatively extensive organizations. As noted in previous research though, parties in the region typically lack such organizational attributes (Levitsky, Loxton, van Dyck, \& Domínguez, 2016), and the data neatly captures the gradual weakening of parties since the 1970s - a trend that has been especially consequential in countries such as Colombia or Venezuela (e.g. Seawright, 2012). Moreover, parties in the region vary significantly with respect to internal decisionmaking procedures. On average, the region still ranks second after Western Europe and North America in that parties tend to have rather decentralized decision-making structures that give more voice to lower cadres while becoming slightly less personalized in recent years (cf. Online Supplement).

In the aftermath of the collapse of single-party communist regimes, most parties in Eastern Europe and Central Asia initially lacked ties to civil society organizations, had a limited social base, and restricted local structures; but reiterations of multiparty elections gradually contributed to organization building since the 1990s (Bugajski, 2002, p. xxiv). V-Party data also indicates that while parties in the region still have negligible ties to civil society organizations, they significantly invested in building nationwide territorial organizations (cf. Online Supplement). Corroborating earlier findings (Enyedi, 2006), the data furthermore demonstrates that parties in the region typically have internal-decision making structures that favor central party leadership at the expense of party members. 


\section{Validating V-Party's Organizational Data}

While V-Party data neatly captures global trends and regional patterns its main utility is the analysis on the party level. To showcase the validity of V-Party data, we now follow Adcock and Collier's (2001) three-pronged strategy: First, we look at the face or content validity of V-Party data by investigating to what extent descriptive patterns match existing expectations about single parties (3.1). Second, for criterion validity we compare the new data to extant data measuring similar concepts (3.2). Finally, for construct validity we test a well-established hypothesis that party organizational features are key drivers of party durability (see e.g Levitsky et al., 2016; Tavits, 2013). We provide global evidence that party's organizational attributes - not country-level factors such as political institutions are the most powerful predictors of party durability (3.3).

\subsection{Content Validity: The Evolution of Selected Party Organizations}

We begin our validation exercise by examining to what extent V-Party data successfully captures patterns of party organizations that have been observed in well-studied parties and thus accurately captures the concepts it intends to measure. We select six well-known political parties from around the globe. Figure 3 plots the development of Alliance 90/The Greens (B90/Grue, Germany), the Hungarian Civic Alliance/Fidesz, Justice and Development Party (AKP, Turkey), the Workers' Party (PT) in Brazil, Mexico's Institutional Revolutionary Party (PRI), and the Liberal Democratic Party (LDP, Japan).

To start with, V-Party data aptly captures the time the German Greens entered government for the first time from 1998 to 2005. Much like other ecologist parties (cf. Schumacher et al., 2013, p. 470) they are strongly activist-dominated in general. Still, the drop in intra-party power concentration towards more centralized structures during that phase reflects a process Müller (1994, p. 73) termed "governmentalization", i.e. "a shift of power from the party organization to the party's team in government". At the same time, the Greens faced some serious "ideological challenges” e.g. the Kosovo war and profound social policy reforms which led to internal furor and a de-alienation of party supporters. Back in opposition they worked on being available for coalition government again by resolving internal frictions (Lees, 2018).

Turning to Fidesz, we observe a steep increase in the party's organizational extensiveness especially during the 1990s when the party significantly expanded its activist base across the country which was coupled with "a spectacular growth in the number of local organizations" (Enyedi \& Linek, 2008, 
p. 465). Fidesz's activist base and local branches have been particularly active across the nation, organizing numerous mass rallies, town hall meetings, and demonstrations. V-Party not only captures the party's entrenched ties to social organizations (Greskovits, 2020) but also Fidesz's transformation from a youth movement to a highly centralized party increasingly being dominated by Victor Orban (Enyedi \& Linek, 2008).

Regarding Turkey's AKP, which has been in power since 2002, our V-Party data suggests that it expanded its organization by investing in local branch structures through which the party maintains highly active community presence (Baykan, 2018), and by cultivating close ties to prominent civil society associations (Esen \& Gumuscu, 2020). Furthermore, the data shows increasing concentration of decision-making authority in the hands of its leader, Tayyip Erdogan (Yardımc1-Geyikçi \& Yavuzyilmaz, 2020). A drop in internal party cohesion since 2010 reflects increasing internal discontent within the party ranks that led some prominent party members to defect to opposition.

Shifting our attention to Latin America, we focus on the Worker's party PT which has been one of the most influential institutional actors in post-authoritarian Brazil. Formed in 1980, PT combines some features of a typical mass party. As our data indicate, the party has a relatively large and active membership base, nationwide network of local branches, and entrenched ties to civil society, in particular to labor unions that provided a major component of the party's membership since its foundation (see Hunter, 2010). As demonstrated in Figure 3, PT's organizational extensiveness experienced a steady growth until 2005 and remained relatively stable since then. PT is often characterized with inclusive decision-making procedures, where rank-and-file members have ample opportunities to participate in party deliberations and manifest their preferences especially through internal elections for key party posts (Samuels, 2004). In recent years though, many observers noted that the former president and party leader, Lula da Silva, increased its grip over the party organization, which is captured by the drop in the intra-power concentration score (Hunter \& Power, 2007).

V-Party also accurately captures the organizational evolution of Mexico's PRI, extensively described in Langston (2017). Beginning from mid-1980s, we observe a gradual decline in the party's organizational extensiveness mainly driven by the weakening ties to civil society organizations. PRI has an extensive network of local branches and active presence across the municipalities, but the economic crises of the 1980s and 1990s and subsequent market-oriented policy responses implemented by the party leadership damaged the party's ties to allied labor unions. This development culminated in serious intra-party conflicts which eventually led to the defection of a major left-leaning internal faction led by Cuauhtémoc Cárdenas. A significant drop in elite cohesion during the 1980s coincides with party ruptures. Relative to its peers, during the authoritarian era the PRI had collegial decision- 
Figure 3 Organizational Evolution of Selected Party Organizations

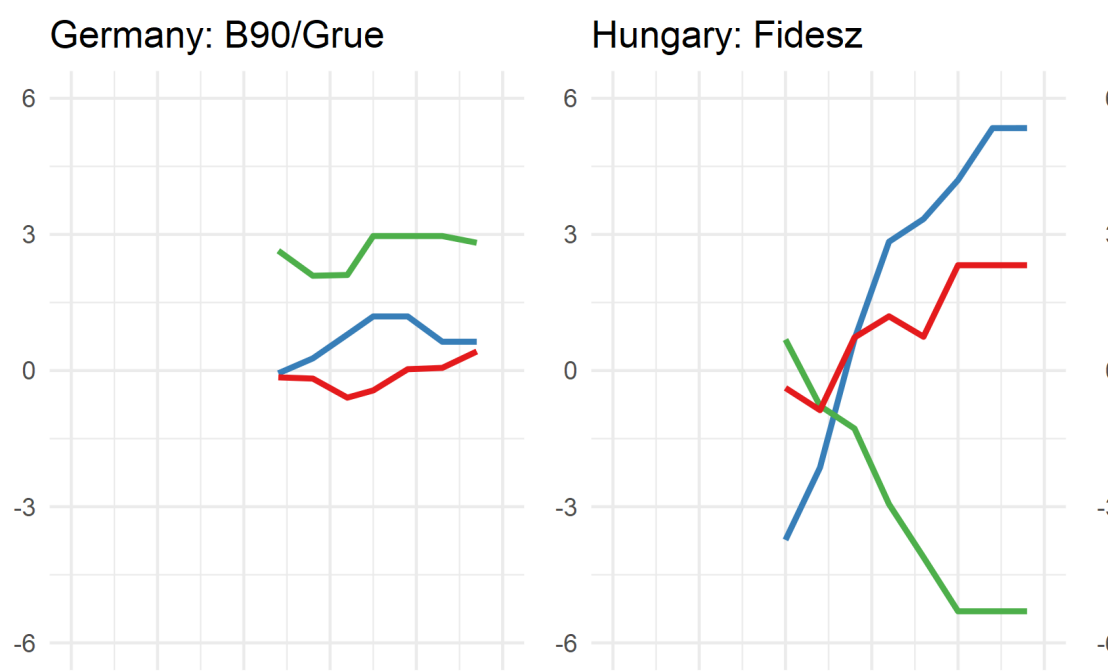

Turkey: AKP

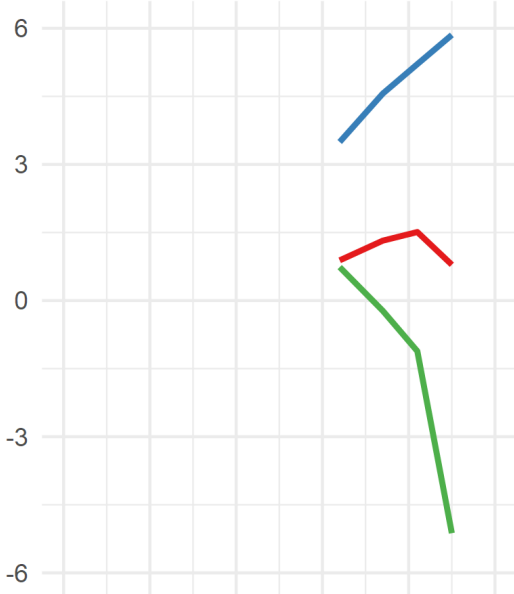

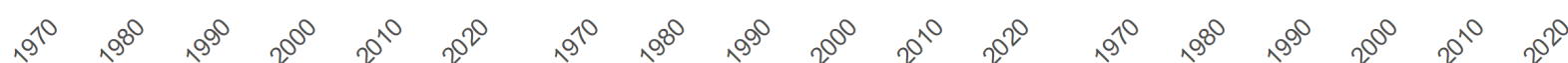

Brazil: PT

Mexico: PRI

6

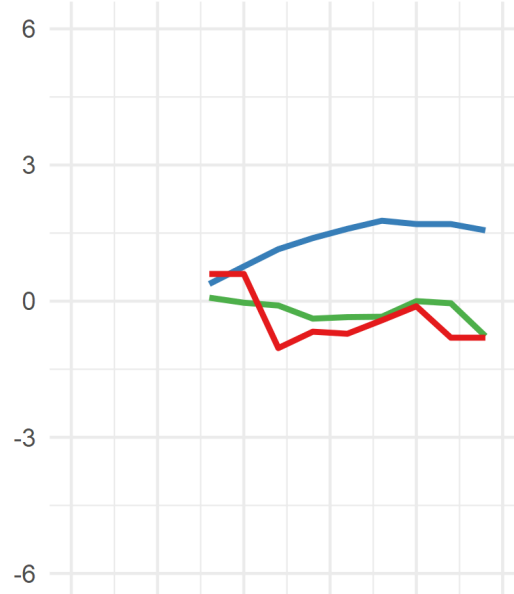

0

$-3$
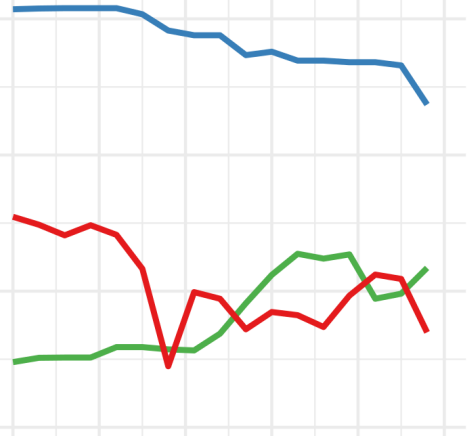

Japan: LDP

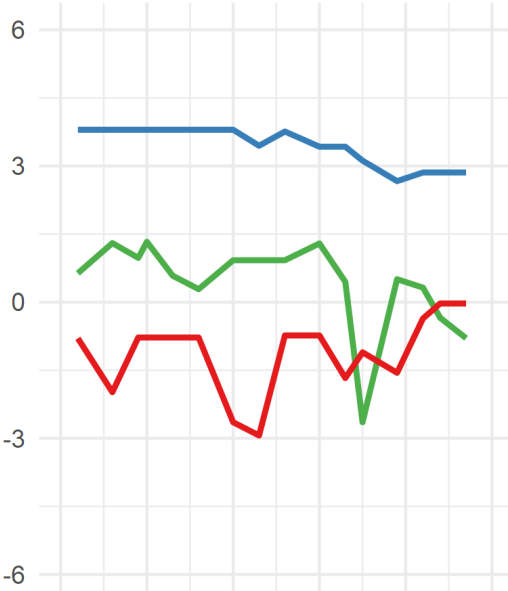

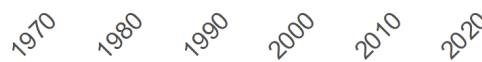

- Organizational extensiveness

- Intra-party power concentration

- Elite cohesion

making procedures and de jure rules such as term limits for party leadership that prevented excessive concentration of power in the hands of an individual party leader. As captured by V-Party data, the internal balance of power increasingly shifted towards lower party cadres, especially since the early 1990s when a series of intra-party reforms decentralized and made legislative candidate selection procedures more inclusive (Langston, 2017).

Finally, we look at LDP, a party that has ruled Japan since its foundation in 1955 - with the exception of a period between 1993-1994, and from 2009 to 2012. LDP is often described as having one of the most extensive organizations among its peers in liberal democracies - an observation supported 
by V-Party data. Nevertheless, we observe a drop in the party's organizational extensiveness especially during the 2010s when the party's ties to prominent social organizations such as farmers' and postmasters' associations weakened drastically (Krauss \& Pekkanen, 2010). The significant drop in cohesion in the late 1980s and early 1990s corresponds to a period when a series of corruption scandals related to prominent party members, internal disagreements about electoral reform proposals, and competition over party leadership exacerbated internal divisions that eventually led more than thirty LDP legislators to split from the party in 1993 (Pempel, 2008). The steep decrease in intra-party power concentration in the early 2000s is in line with case studies suggesting that the party's leader at that time, Junichiro Koizumi, skillfully concentrated more power in his hands by curbing the influence of powerful intra-party factions (Pempel, 2008).

V-Party data successfully captures the evolution of individual party organizations over time. Therefore, we can be confident that the measures indeed capture the concept they claim to measure and the close examination of six selected parties underlines V-Party's high level of content or face validity. Adcock and Collier (2001, p. 539) still remind us that content validation alone "is incomplete". We therefore examine the criterion validity by pitting V-Party items against extant data measuring similar concepts.

\subsection{Criterion Validity: Comparing Measures of Party Organization}

Although V-Party is unique in terms of scope and coverage, few other data collections tapped party organizational features as well. This includes Kitschelt's (2013) “Democratic Accountability and Linkages Project" (DALP), the "Political Parties Database Project" (PPDB) (Poguntke et al., 2016) or Giger and Schumacher's (2015) compilation of a diverse set of older expert surveys ${ }^{2}$ in their "Integrated Party Organization Dataset" (IPOD). V-Party asked experts to rate the identity and party organizational features on an election-year basis; for other surveys the reference time seldom matches an election year though, or is not explicitly mentioned at all. For overlapping parties $N$, we therefore performed a "fuzzy match" of V-Party data in a range of minus five years to the year the expert survey either referred to or was published $(n) .^{3}$ Figure 4 plots V-Party items and dimensions of party-organizational features against extant data. We also report additional checks against further items that can be found in the Online Supplement.

\footnotetext{
2 Among others Rohrschneider \& Whitefield, 2012; Janda, 1980; Laver \& Hunt, 1992.

3 Strictly speaking, due to different wordings of the survey questions the items are not directly comparable. Still, they usually attempt to uncover organizational features similar to the V-Party items.
} 
To start with, the upper graphs show a quite strong correlation of $v 2$ pasoctie, capturing the extent to which a party maintains ties to prominent social organizations, and the organizational extensiveness dimension with data from Rohrschneider and Whitefield's (2012) survey who asked whether a party has an organizational affiliation with any interest or civil society group. Similarly, the responses to their question about a "significant membership base" positively correlate with $v 2$ paactcom, asking for active local communities, and the aggregate measure $(r=0.652, \mathrm{p}<0.001$ and $\mathrm{r}=0.607, \mathrm{p}<0.001)$. The aggregate measure also correlates on a reasonable level with a formal aspect from the PPDB, the "total number of individual plus corporate (indirect) members" $(\mathrm{r}=0.328, \mathrm{p}<0.005)$. The DALP in turn asked whether parties maintain offices and paid staff permanently at the municipal level or only during national elections with response categories ranging from permanent local offices in most districts to not at all (hence the negative sign for v2palocoff and the aggregate measure). As expected, the second line in Figure 4 shows a quite strong correlation with responses from Kitschelt's survey. For the PPDB, Poguntke et al. (2016) asked for the number of the smallest party units represented at higher levels. While being formal and very specific, $v 2$ palocoff and our aggregate measure correlate on a decent level $(r=0.551, \mathrm{p}<0.001$ and $\mathrm{r}=0.559, \mathrm{p}<0.001)$. Finally, the organizational extensiveness measure points in the same direction as Janda's (1980) six-point question whether there are local party organs or whether a party solely organizes at the national level $(\rho=0.383, \mathrm{p}<0.001)$. Correlating with a broad set of empirical facets, V-Party data aligns well with extant data on party's organizational extensiveness.

Looking at the intra-party power concentration, Schumacher and Giger (2017, pp. 168-170) construct a measure of "leadership domination" combining several items from expert survey data, among others Laver and Hunt (1992), Harmel and Janda (1994), or Rohrschneider and Whitefield (2012). As the third line in Figure 4 shows, their measure correlates neatly with both the variable $v 2$ paind, asking to what extent a party is a vehicle for the personal will of one individual leader ${ }^{4}$, and our aggregate measure of intra-party power concentration. As they are part of Schumacher and Giger's index, unsurprisingly both $v 2$ paind, v2panom (focusing on the candidate nomination process), and the aggregate measure correlate quite strongly with the original items (cf. Online Supplement). The results look similar when looking at Kitschelt's (2013) question asking for the way candidates are selected for national legislative elections ranging from national party leaders to local/municipal actors. Expectedly, $v 2$ panom and the intra-party power concentration index correlate on a high level $(\mathrm{r}=0.639, \mathrm{p}<0.001$ and $\mathrm{r}=0.686, \mathrm{p}<0.001)$.

\footnotetext{
${ }^{4}$ Reversed scale to ease the interpretation.
} 
Figure 4 Validating V-Party Data Against Extant Surveys
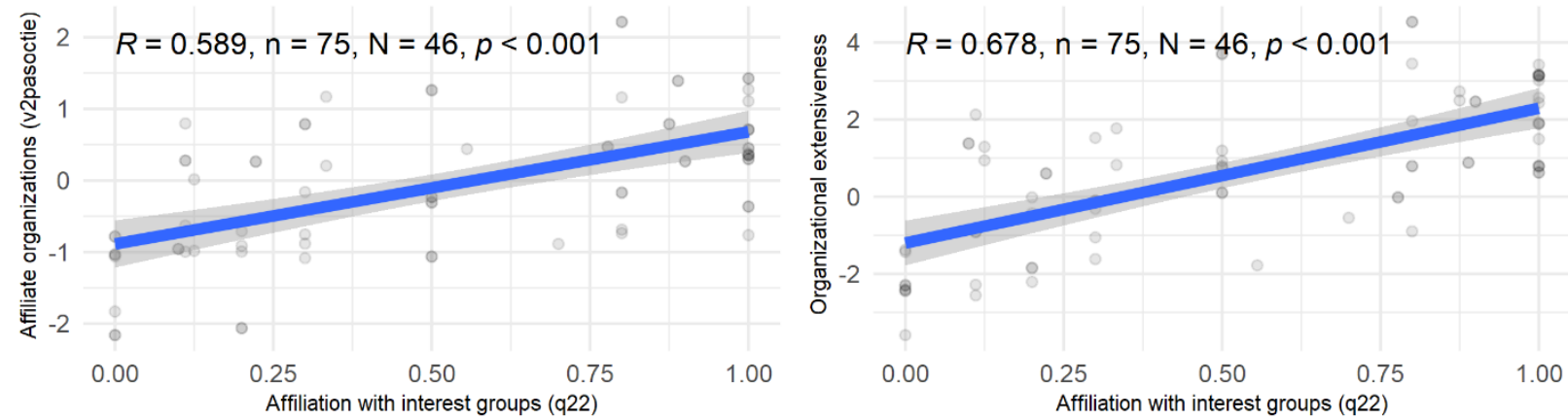

Rohrschneider and Whitefield (2012)
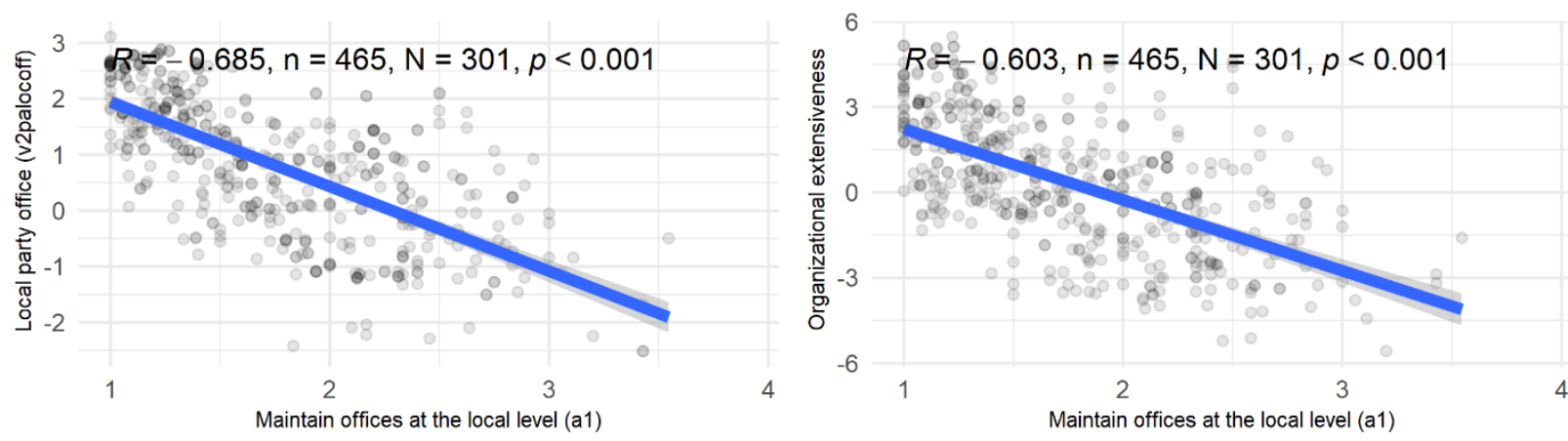

Kitschelt (2013)
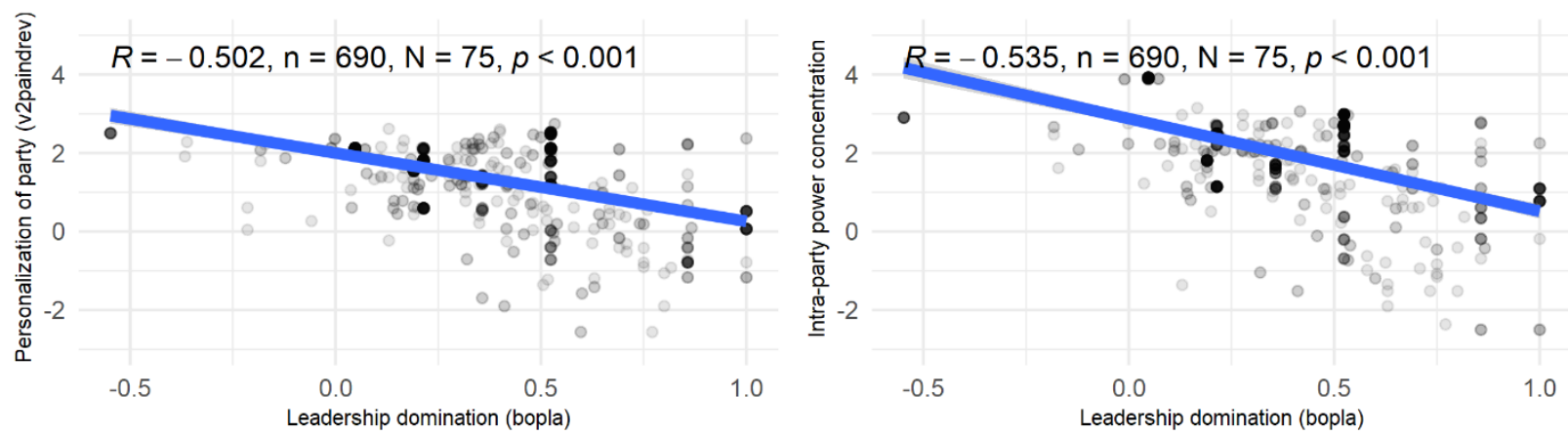

Schumacher and Giger (2017)
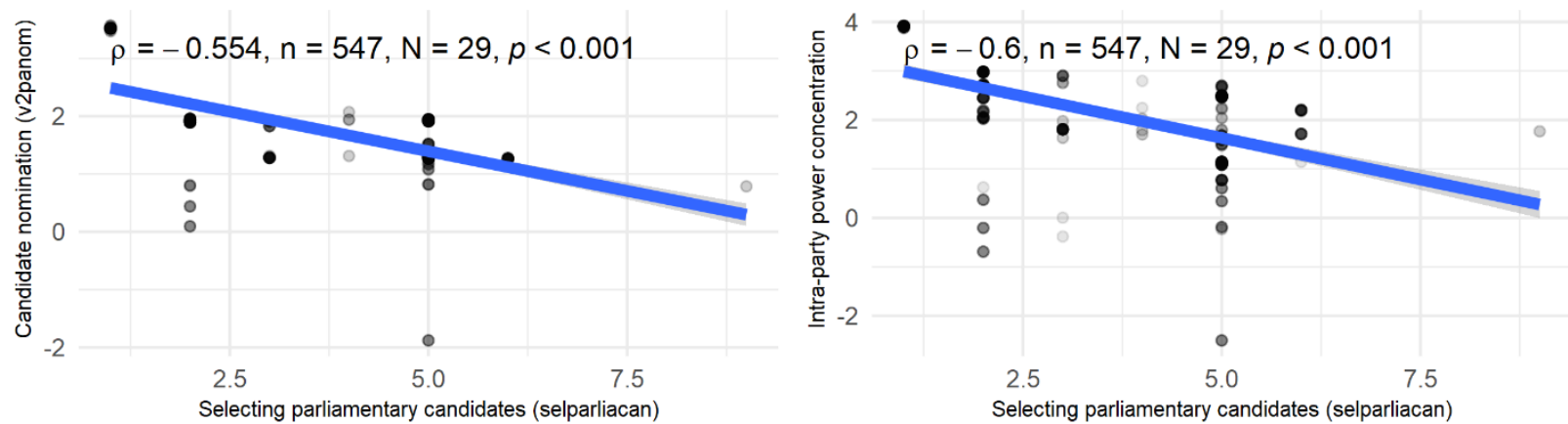

Janda (1980)

Notes: $\mathrm{n}=$ number of "fuzzy matched" observations, $\mathrm{N}=$ number of unique, overlapping parties; gray area denotes 95 percent confidence interval. 
As the lowest graphs in Figure 4 show, V-Party data on candidate nomination also correlates with data from Janda (1980) capturing who is in charge of selecting parliamentary candidates with responses ranging from local supporters to the national committee. Moreover, Poguntke et al. (2016, 669-670) provide data on the statutory power of party leaders on nine different issues (e.g. whether a party leader may summon party officials, select deputy leaders, or must consent to coalition agreements) which can be added up for an "index of leadership strength". Focusing on formal rules in a very specific sense, even here $v 2$ paind $(\rho=0.412, \mathrm{p}=0.001)$ shows a reasonable correlation pointing in the same direction. This underlines that V-Party data is well suited for capturing the intra-party power concentration of parties.

Finally, Janda (1980) also had three measures asking whether there is struggle over leadership, over party strategy and tactics or over ideological concerns ranging from little to no disagreement up to the point that larger factions have been established, at times with their own formal, internal organization (hence a negative sign is expected). For the former two we only find a weak to modest correlation with $v 2$ padisa, capturing elite cohesion $(\rho=-0.386, \mathrm{p}=0.007$ and $\rho=-0.079, \mathrm{p}=0.614$, respectively). However, there is a quite strong correlation regarding ideological concerns $(\rho=-0.541, \mathrm{p}<0.001)$, again supporting Tavits (2011), LeBas (2011) and Levitsky and Way's (2010) notion that cohesion is a distinct dimension of party organizations.

According to Adcock and Collier (2001, p. 540), the basic idea of criterion or convergent validity is that two indicators aiming at measuring the same theoretical concept should show stronger associations, while weaker associations indicate that two indicators measure different things. Given that the surveys differ with regards to the precise wording of questions, response categories, operationalizations (e.g., the PPDB's focus on formal rules) and time period covered, one would not expect too much of an overlap. Still, V-Party data aligns well with extant data on party organizational characteristics both from more recent surveys as well as older data reaching back to the 1980s. This puts confidence in utilizing V-Party data for longitudinal and cross-country analyses of the organizational extensiveness of parties, the intra-party power concentration and elite cohesion on a much broader scale than before. Yet, Adcock and Collier (2001, p. 542) call for a third perspective on measurement validity which they call "AHEM validation; that is, "Assume the Hypothesis, Evaluate the Measure" - to which we will now turn. 


\subsection{Construct Validity: Party Organizations and Persistence Revisited}

To evaluate the construct validity of V-Party measures, we examine the association between party organizational features and the survival of political parties. Previous research highlighted that parties with strong grassroots organizations and ties to social groups are more likely to survive - and thrive - than those without such organizations (Beyens, Lucardie, \& Deschouwer, 2016; Kitschelt \& Wilkinson, 2007; Samuels \& Zucco, 2015; Scarrow, 1994; Tavits, 2012). Moreover, the literature makes clear that schisms and defections undermine party survival whereas internally cohesive parties tend to be more stable (Boucek, 2009; Brownlee, 2007; Levitsky \& Way, 2010).

By contrast, there is less consensus on the relationship between internal power concentration and party survival. Several studies argue that centralized decision-making structures can boost parties' capacity to quickly respond to changing competitive dynamics because the dispersion of decisionmaking power among large groups of party members can induce strategic inertia (Kitschelt, 1994; Meyer, 2013). Yet, the flexibility of centralized parties may also make them vulnerable to breakdown especially when they are excessively dominated by an individual party leader. In such cases, scandals, electoral defeats, or the death of a leader can imperil the entire party (Panebianco, 1988). Scholars of autocracy also argue that increasing power concentration in the hands of dictators undermine party durability. When parties are run capriciously by the dictator, party cadres have fewer reasons to believe that their loyalty will be rewarded with long-term career advancement. This increases party elites' incentives to defect and makes parties more unstable (e.g. Magaloni, 2008; Svolik, 2012).

Resuming the "AHEM validation", we draw on previous research and assess the impact of party organizational extensiveness, cohesion, and intra-party power concentration on the likelihood of party breakdown. Our sample includes 1515 parties from 150 countries between 1970 and 2019. Employing a discreet event history modeling framework (Box-Steffensmeier \& Jones, 2004), our dependent variable is party breakdown denoting whether a party's vote share falls below 5 percent in a given national legislative election. ${ }^{5}$ We fit random intercept logit models, allowing intercepts to vary by party and country. To account for duration dependence (Carter \& Signorino, 2010), all models include the natural logarithm of duration. We control for several potential confounders that are likely to be related to party organizational features and party breakdown. Descriptive statistics, alternative model specifications, and regression tables can be found on the Online Supplement.

\footnotetext{
${ }^{5}$ Unfortunately, applying more fine-grained operationalizations of "party death" (see e.g. Bolleyer, Correa, \& Katz, 2019) is unfeasible given the global scope of V-Party. We do, however, take instances into account where a party just shortly falls below this threshold and re-appears again. In a strict sense, a party and its organization may still be "alive" but it permanently lost its ability to seriously influence politics. This definition and threshold are sufficient for current purposes.
} 
Figure 5 Predictors of Party Breakdown, 1970-2019

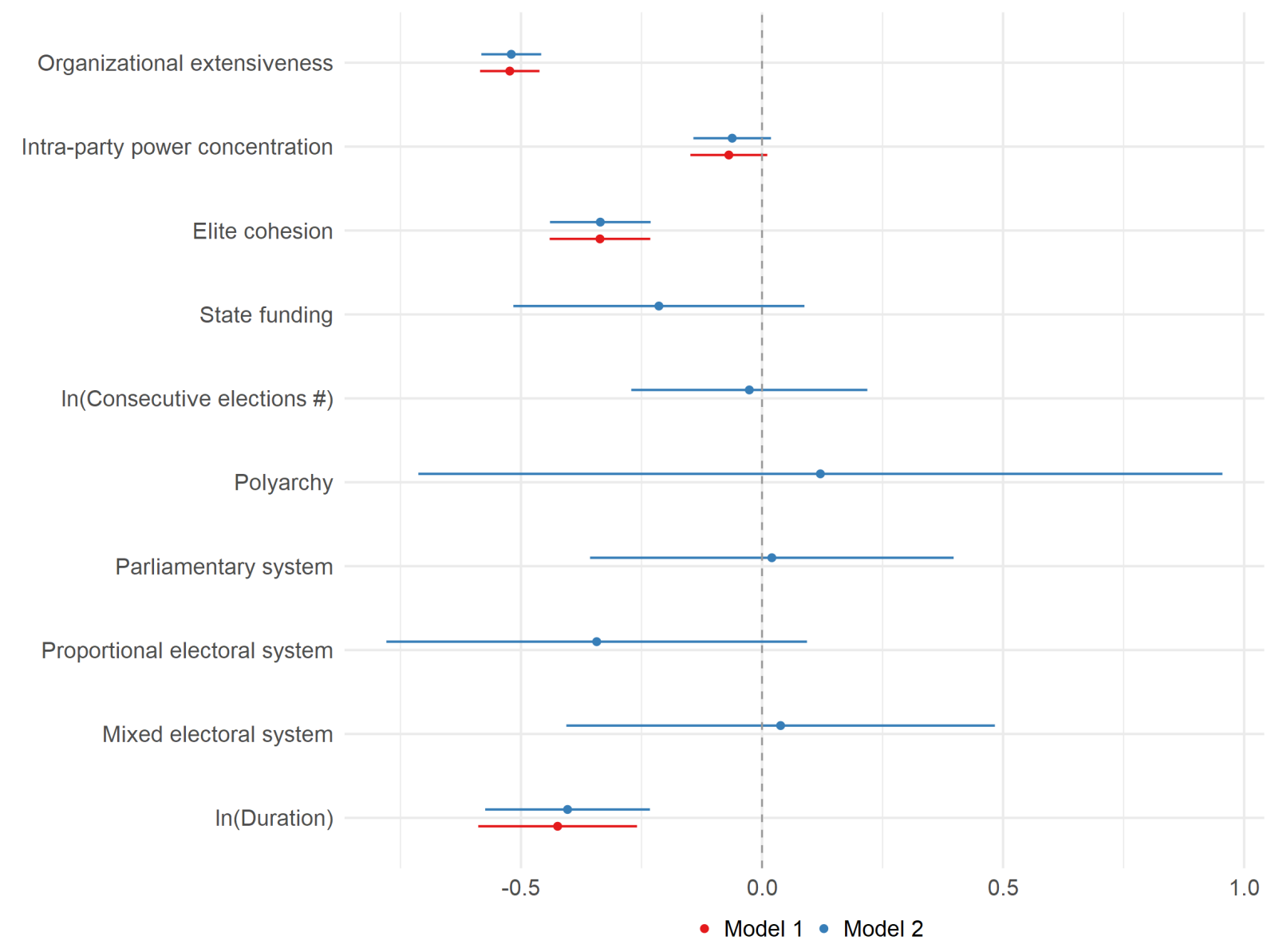

Note: Random intercepts logistic regression coefficient estimates (dots) with 95 percent confidence intervals (horizontal line).

Figure 6 Predicted Probabilities of Party Breakdown (with 95 percent CIs)
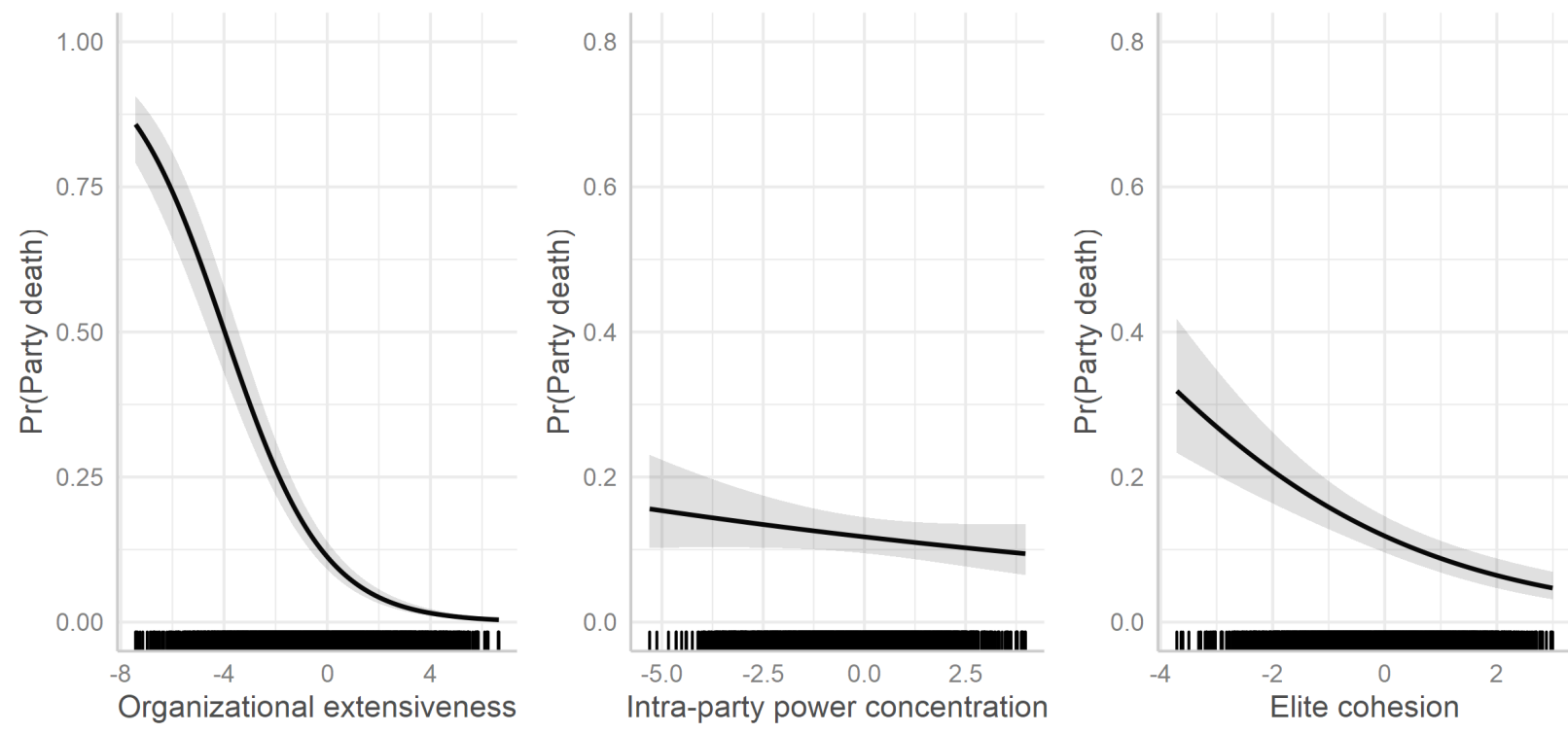
Figure 5 plots the results. Model 1 solely includes our three dimensions of party organizational features and the natural logarithm of duration. The results suggests that party organizational extensiveness is negatively associated with the probability of party breakdown $(\mathrm{p}<0.001)$. Moreover, devolution of decision-making authority from party leadership to lower cadres reduces the probability of party breakdown as indicated by the negative coefficient for the intra-party concentration index $(\mathrm{p}<0.05)$. Elite cohesion expectedly plays an important role in party survival $(p<0.001)$ as well.

The results remain robust when entering potential confounders. Model 2 highlights the importance of party organizational aspects over contextual factors in shaping party durability. The coefficients for the number of consecutive elections, level of democracy (polyarchy), type of government (parliamentary versus presidential), and electoral system (proportional and mixed systems compared to majoritarian systems) are not statistically different from Zero.

Figure 6 plots the predicted probabilities from our main models. Strong grassroots organizations and elite cohesion are strongly and negatively associated with party breakdown. On average, a one standard deviation decrease from the mean organization extensiveness increases the probability of party breakdown from 12 to 35 percent. The substantive effect of intra-party power concentration is much smaller than for elite cohesion or grassroots organization. As noted above, this accords with the findings from previous studies.

Representing the first global analysis, our "AHEM validation" corroborates earlier findings how organizational features shape the durability of parties. It underlines that parties with extensive organizations survive longer than others, while conflict-ridden parties are expected to much more frail than cohesive parties. In sum, our analysis of party breakdown using V-Party indicators lends support for existing theoretical expectations, and therefore provides positive evidence for the nomological validity of V-Party data. 


\section{Conclusion}

V-Party opens up new avenues for comparative research on the causes and consequences of organizational characteristics of individual political parties. It provides longitudinal measures of parties' local branches, ties to social organizations, candidate nomination procedures, personalization, and internal cohesion for more than 1,900 parties in 168 countries between 1970 and 2019. For many polities around the world, V-Party provides the first-ever data on party organizations.

To show the usefulness and emphasize the potential of V-Party, we introduced the survey, its (methodological) foundation and provided some first, descriptive impressions on global and regional trends neatly captured by the data. We then put it to a systematic test by validating the data following Adcock and Collier's (2001) three-pronged strategy. First, we examined face or content validity by illustrating V-Party's ability to accurately capture the dynamics of party organizational features of wellstudied parties over time. We further investigated the validity by comparing the new data to measures from other expert surveys. As V-Party aligns well with extant data on party organizational characteristics - both from more recent surveys (e.g. Kitschelt, 2013) as well as older ones reaching back to the 1980s (e.g. Janda, 1980) - we conclude that it provides sufficient criterion validity. Finally, in order to establish construct validity, we showed that V-Party's measures of grassroots organization and elite cohesion corroborate earlier findings on the impact of party organizational characteristics on party survival.

In sum, V-Party provides a new and rich source of valid data to test old theories in new contexts, re-assess and expand existing knowledge on party organizations, and tackle pressing questions in a systematic and comparative manner - for the first time from a global perspective; and we hope that scholars will make ample use of this new resource. 


\section{References}

Adcock, R., \& Collier, D. (2001). Measurement Validity: A Shared Standard for Qualitative and Quantitative Research. American Political Science Review, 95(3), 529-546. https://doi.org/10.1017/S0003055401003100

Baykan, T. S. (2018). The Justice and Development Party in Turkey: Populism, personalism, organization. Cambridge: Cambridge University Press. https://doi.org/10.1017/9781108570725

Bernhard, M., Hicken, A., Reenock, C., \& Lindberg, S. I. (2020). Parties, Civil Society, and the Deterrence of Democratic Defection. Studies in Comparative International Development, 55(1), 1-26. https://doi.org/10.1007/s12116-019-09295-0

Beyens, S., Lucardie, P., \& Deschouwer, K. (2016). The Life and Death of New Political Parties in the Low Countries. West European Politics, 39(2), 257-277. https://doi.org/10.1080/01402382.2015.1066589

Bizzarro, F., Gerring, J., Knutsen, C. H., Hicken, A., Bernhard, M., Skaaning, S.-E., . . Lindberg, S. I. (2018). Party Strength and Economic Growth. World Politics, 70(2), 275-320. https://doi.org/10.1017/S0043887117000375

Blondel, J., Thiébault, J.-L., Czernicka, K., Inoguchi, T., Pathmanand, U., \& Venturino, F. (2010). Political Leadership, Parties and Citizens: The Personalisation of Leadership. London: Routledge.

Bolleyer, N., Correa, P., \& Katz, G. (2019). Political Party Mortality in Established Party Systems: A Hierarchical Competing Risks Approach. Comparative Political Studies, 52(1), 36-68. https://doi.org/10.1177/0010414018758764

Boucek, F. (2009). Rethinking Factionalism. Party Politics, 15(4), 455-485. https://doi.org/10.1177/1354068809334553

Bowler, S., Farrell, D. M., \& Katz, R. S. (1999). Party Cohesion, Party Discipline, and Parliaments. In S. Bowler, D. M. Farrell, \& R. S. Katz (Eds.), Party Discipline and Parliamentary Government (pp. 3-22). Columbus: Ohio State University Press.

Box-Steffensmeier, J. M., \& Jones, B. S. (2004). Event History Modeling: A Guide for Social Scientists. Cambridge: Cambridge University Press. https://doi.org/10.1017/CBO9780511790874

Brownlee, J. (2007). Authoritarianism in an Age of Democratization. Cambridge: Cambridge University Press. https://doi.org/10.1017/CBO9780511802348

Bugajski, J. (2002). Political Parties of Eastern Europe: A Guide to Politics in the Post-Communist Era. Armonk, NY: Sharpe.

Carter, D. B., \& Signorino, C. S. (2010). Back to the Future: Modeling Time Dependence in Binary Data. Political Analysis, 18(3), 271-292. https://doi.org/10.1093/pan/mpq013

Comrey, A. L., \& Lee, H. B. (1992). A First Course in Factor Analysis (2nd ed.). New York: Taylor and Francis. Retrieved from http://gbv.eblib.com/patron/FullRecord.aspx?p=1562106

Coppedge, M. (1998). The Dynamic Diversity of Latin American Party Systems. Party Politics, 4(4), 547-568. https://doi.org/10.1177/1354068898004004007

Coppedge, M., Gerring, J., Knutsen, C. H., Lindberg, S., Teorell, J., Alizada, N., . . Römer, J. von (2020). V-Dem Organization and Management v10. Gothenburg. Retrieved from University of Gothenburg, Varieties of Democracy Institute (V-Dem) website: https://www.vdem.net/en/data/reference-materials-v10/

Coppedge, M., Gerring, J., Knutsen, C. H., Lindberg, S. I., Teorell, J., Marquardt, K. L., . . Wilson, S. (2020). V-Dem Methodology v10. Gothenburg. Retrieved from University of Gothenburg, Varieties of Democracy Institute (V-Dem) website: https://www.v-dem.net/en/data/referencematerials-v10/ 
Dalton, R. J., \& Wattenberg, M. P. (Eds.) (2000). Parties Without Partisans: Political Change in Advanced Industrial Democracies. Oxford: Oxford University Press.

Döring, H., \& Düpont, N. (2020). Elections Global: Election results in 207 countries, 1880-2015: Harvard Dataverse. Retrieved from https://dataverse.harvard.edu/citation?persistentId=doi:10.7910/DVN/OGOURC

Döring, H., \& Regel, S. (2019). Party Facts: A Database of Political Parties Worldwide. Party Politics, 25(2), 97-109. https://doi.org/10.1177/1354068818820671

Druckman, J. N. (1996). Party Factionalism and Cabinet Durability. Party Politics, 2(3), 397-407. https://doi.org/10.1177/1354068896002003006

Duverger, M. ([1951] 1981). Les Partis Politiques (10th ed.). Paris: Colin.

Elischer, S. (2013). Political Parties in Africa: Ethnicity and Party Formation. Cambridge: Cambridge University Press. https://doi.org/10.1017/CBO9781139519755

Enyedi, Z. (2006). Party Politics in Post-Communist Transition. In R. S. Katz \& W. Crotty (Eds.), Handbook of Party Politics (pp. 228-238). London: Sage.

Enyedi, Z., \& Linek, L. (2008). Searching for the Right Organization. Party Politics, 14(4), 455-477. https://doi.org/10.1177/1354068808090255

Esen, B., \& Gumuscu, S. (2020). Why did Turkish democracy collapse? A political economy account of AKP's authoritarianism. Party Politics, Online first May 11, 2020. https://doi.org/10.1177/1354068820923722

Giannetti, D., \& Benoit, K. (Eds.) (2009). Intra-Party Politics and Coalition Governments. London: Routledge.

Giger, N., \& Schumacher, G. (2015). Integrated Party Organization Dataset (IPOD). https://doi.org/10.7910/DVN/PE8TWP

Greskovits, B. (2020). Rebuilding the Hungarian Right through Conquering Civil Society: the Civic Circles Movement. East European Politics, 36(2), 247-266. https://doi.org/10.1080/21599165.2020.1718657

Harmel, R., \& Janda, K. (1994). An Integrated Theory of Party Goals and Party Change. Journal of Theoretical Politics, 6(3), 259-287.

Hazan, R. Y. (2003). Introduction: Does cohesion equal discipline? Towards a conceptual delineation. The Journal of Legislative Studies, 9(4), 1-11. https:/ / doi.org/10.1080/1357233042000306227

Hix, S. (2001). Legislative Behaviour and Party Competition in the European Parliament: An Application of Nominate to the EU. Journal of Common Market Studies, 39(4), 663-688.

Hunter, W. (2010). The Transformation of the Workers' Party in Brazil, 1989-2009. Cambridge: Cambridge University Press. https://doi.org/10.1017/CBO9780511763304

Hunter, W., \& Power, T. J. (2007). Rewarding Lula: Executive Power, Social Policy, and the Brazilian Elections of 2006. Latin American Politics and Society, 49(1), 1-30. https://doi.org/10.1111/j.1548-2456.2007.tb00372.x

Ichino, N., \& Nathan, N. L. (2012). Primaries on Demand? Intra-Party Politics and Nominations in Ghana. British Journal of Political Science, 42(4), 769-791. https://doi.org/10.1017/S0007123412000014

Janda, K. (1980). Political Parties: A Cross-National Survey. New York: Free Press.

Katz, R. S., \& Mair, P. (1993). The Evolution of Party Organizations in Europe: The Three Faces of Party Organization. American Review of Politics, 14, 593-617.

Katz, R. S., \& Mair, P. (Eds.) (1994). How Parties Organize: Change and Adaptation in Party Organizations in Western Democracies. London: Sage. 
Kavasoglu, B. (2021). Autocratic Ruling Parties During Regime Transitions: Investigating the Democratizing Effect of Strong Ruling Parties. Party Politics, First published online January 5, 2021. https://doi.org/10.1177/1354068820985280

Kirchheimer, O. (1965). Der Wandel des Westeuropäischen Parteisystems. Politische Vierteljahresschrift, 6(1), 20-41.

Kitschelt, H. (1994). The Transformation of European Social Democracy. Cambridge Studies in Comparative Politics. Cambridge: Cambridge University Press.

Kitschelt, H. (2013). Democratic Accountability and Linkages Project: 2008-9 Dataset. Retrieved from Duke University website: https://sites.duke.edu/democracylinkage

Kitschelt, H., \& Wilkinson, S. (Eds.) (2007). Patrons, Clients, and Policies: Patterns of Democratic Accountability and Political Competition. Cambridge: Cambridge University Press. https://doi.org/10.1017/CBO9780511585869

Krauss, E. S., \& Pekkanen, R. J. (2010). The Rise and Fall of Japan's Liberal Democratic Party. The Journal of Asian Studies, 69(1), 5-15. https://doi.org/10.1017/S0021911809992555

Langston, J. K. (2017). Democratization and Authoritarian Party Survival: Mexico's PRI. New York: Oxford University Press. Retrieved from http:/ / search.ebscohost.com/login.aspx?direct $=$ true\&scope $=$ site $\& \mathrm{db}=$ nlebk\&AN $=1500889$

Laver, M., \& Hunt, W. B. (1992). Policy and Party Competition. New York: Routledge.

LeBas, A. (2011). From Protest to Parties: Party-Building and Democratization in Africa. Oxford: Oxford University Press.

Lees, C. (2018). The German Greens and the 2017 Federal Election: Between Strategic Calculation and Real-World Politics. German Politics, 27(1), 124-130. https://doi.org/10.1080/09644008.2018.1437905

Levitsky, S. (2001). Organization and Laborbased Party Adaption: The Transformation of Argentine Peronism in Comparative Perspective. World Politics, 54(October), 27-56.

Levitsky, S., \& Cameron, M. A. (2003). Democracy without Parties? Political Parties and Regime Change in Fujimori's Peru. Latin American Politics and Society, 45(03), 1-33. https://doi.org/10.1111/j.1548-2456.2003.tb00248.x

Levitsky, S., Loxton, J., van Dyck, B., \& Domínguez, J. I. (Eds.) (2016). Challenges of Party-Building in Latin America. New York: Cambridge University Press. https://doi.org/10.1017/CBO9781316550564

Levitsky, S., \& Way, L. A. (2010). Competitive Authoritarianism: Hybrid Regimes after the Cold War. Cambridge: Cambridge University Press. https://doi.org/10.1017/CBO9780511781353

Lindberg, S. I. (2007). Institutionalization of Party Systems? Stability and Fluidity among Legislative Parties in Africa's Democracies. Government and Opposition, 42(2), 215-241. https://doi.org/10.1111/j.1477-7053.2007.00219.x

Lührmann, A., Düpont, N., Higashijima, M., Kavasoglu, Y. B., Marquardt, K. L., Bernhard, M., . . . Seim, B. (2020). Varieties of Party Identity and Organization (V-Party) Dataset V1. Göteborg. https://doi.org/10.23696/vpartydsv1

Lührmann, A., Medzihorsky, J., \& Lindberg, S. I. (2021). Walking the Talk: How to Identify Anti-Pluralist Parties (V-Dem Working Paper No. 116).

Lührmann, A., Tannenberg, M., \& Lindberg, S. I. (2018). Regimes of the World (RoW): Opening New Avenues for the Comparative Study of Political Regimes. Politics and Governance, 6(1), 60-77. https://doi.org/10.17645/pag.v6i1.1214 
Magaloni, B. (2008). Credible Power-Sharing and the Longevity of Authoritarian Rule. Comparative Political Studies, 41(4-5), 715-741. https://doi.org/10.1177/0010414007313124

Mainwaring, S., \& Linan, A. P. (1997). Party Discipline in the Brazilian Constitutional Congress. Legislative Studies Quarterly, 22(4), 453. https://doi.org/10.2307/440339

Meyer, T. M. (2013). Constraints on Party Policy Change. Colchester: ECPR Press.

Michels, R. ([1911] 1962). Political Parties: A Sociological Study of the Oligarchical Tendencies of Modern Democracy. New York: Free Press.

Müller, W. C. (1994). The Development of Austrian Party Organizations in the Post-war Period. In R. S. Katz \& P. Mair (Eds.), How Parties Organize: Change and Adaptation in Party Organizations in Western Democracies (pp. 51-79). London: Sage.

Nájera, A. E. (2010). Party Systems and Democracy after the Conflicts: El Salvador Guatemala and Nicaragua. University of Notre Dame. Retrieved from https://curate.nd.edu/show/zg64th8669w

Olson, D. M. (2003). Cohesion and Discipline Revisited: Contingent Unity in the Parliamentary Party Group. The Journal of Legislative Studies, 9(4), 164-178. https://doi.org/10.1080/1357233042000306326

Panebianco, A. (1988). Political Parties: Organization and Power. Cambridge: Cambridge University Press.

Pempel, T. J. (2008). Learning to Lose is for Losers: The Japanese LDP's Reform Struggle. In J. Wong \& E. Friedman (Eds.), Political Transitions in Dominant Party Systems (pp. 109-126). Routledge.

Pemstein, D., Marquardt, K. L., Tzelgov, E., Wang, Y., Medzihorsky, J., Krusell, J., . . . Römer, J. von (2019). The V-Dem Measurement Model: Latent V ariable Analysis for Cross-National and Cross-Temporal Expert-Coded Data (V-Dem Working Paper No. 21).

Poguntke, T., Scarrow, S. E., Webb, P., Allern, E. H., Aylott, N., van Biezen, I., . . Verge, T. (2016). Party rules, party resources and the politics of parliamentary democracies: How parties organize in the 21st century. Party Politics, 22(6), 661-678. https://doi.org/10.1177/1354068816662493

Poguntke, T., \& Webb, P. (Eds.) (2007). The Presidentialization of Politics: A Comparative Study of Modern Democracies. Oxford: Oxford University Press.

Rasmussen, M. B., \& Knutsen, C. H. (2019). Party Institutionalization and Welfare State Development. British Journal of Political Science, 1-27. https://doi.org/10.1017/S0007123419000498

Reuter, O. J. (2021). Why Do Ruling Parties Extend Authoritarian Rule? Examining the Role of Elite Institutions and Mass Organization (Working Paper No. 2021:118). Gothenburg.

Rohrschneider, R., \& Whitefield, S. (2012). The Strain of Representation: How Parties Represent Diverse Voters in Western and Eastern Europe. Oxford: Oxford University Press.

Samuels, D. (2004). From Socialism to Social Democracy. Comparative Political Studies, 37(9), 999_ 1024. https://doi.org/10.1177/0010414004268856

Samuels, D., \& Zucco, C. (2015). Crafting Mass Partisanship at the Grass Roots. British Journal of Political Science, 45(4), 755-775. https://doi.org/10.1017/S0007123413000549

Scarrow, S. E. (1994). The 'paradox of enrollment': Assessing the costs and benefits of party memberships. European Journal of Political Research, 25(1), 41-60. https://doi.org/10.1111/j.14756765.1994.tb01200.x

Schleiter, P., \& Voznaya, A. (2018). Party System Institutionalization, Accountability and Governmental Corruption. British Journal of Political Science, 48(2), 315-342.

https://doi.org/10.1017/S0007123415000770 
Schumacher, G., \& Giger, N. (2017). Who Leads the Party? On Membership Size, Selectorates and Party Oligarchy. Political Studies, 65(1S), 162-181. https://doi.org/10.1177/0032321716667957

Schumacher, G., \& Giger, N. (2018). Do leadership-dominated parties change more? Journal of Elections, Public Opinion and Parties, 28(3), 349-360. https://doi.org/10.1080/17457289.2017.1403920

Schumacher, G., Vries, C. de, \& Vis, B. (2013). Why Do Parties Change Position? Party Organization and Environmental Incentives. Journal of Politics, 75(2), 464-477. https://doi.org/10.1017/S0022381613000145

Seawright, J. (2012). Party-System Collapse: The Roots of Crisis in Peru and Venezuela. Palo Alto: Stanford University Press. Retrieved from http://gbv.eblib.com/patron/FullRecord.aspx?p=1046400

Seeberg, M. B., Wahman, M., \& Skaaning, S.-E. (2018). Candidate Nomination, Intra-Party Democracy, and Election Violence in Africa. Democratization, 25(6), 959-977. https://doi.org/10.1080/13510347.2017.1420057

Svolik, M. W. (2012). The Politics of Authoritarian Rule. Cambridge: Cambridge University Press. https://doi.org/10.1017/CBO9781139176040

Tavits, M. (2011). Party Organizational Strength and Party Unity in Post-communist Europe. European Political Science Review, 1-23.

Tavits, M. (2012). Organizing for Success: Party Organizational Strength and Electoral Performance in Postcommunist Europe. The Journal of Politics, 74(1), 83-97. https://doi.org/10.1017/S0022381611001198

Tavits, M. (2013). Post-Communist Democracies and Party Organization. Cambridge: Cambridge University Press. https://doi.org/10.1017/CBO9781139565196

Wahman, M. (2017). Nationalized Incumbents and Regional Challengers. Party Politics, 23(3), 309322. https://doi.org/10.1177/1354068815596515

Weghorst, K. R., \& Bernhard, M. (2014). From Formlessness to Structure? The Institutionalization of Competitive Party Systems in Africa. Comparative Political Studies, 47(12), 1707-1737. https://doi.org/10.1177/0010414013516068

Wills-Otero, L. (2016). The electoral performance of Latin American traditional parties, 1978-2006. Party Politics, 22(6), 758-772. https://doi.org/10.1177/1354068814563971

Yardımc1-Geyikçi, S.., \& Yavuzyilmaz, H. (2020). Party (de)institutionalization in times of political uncertainty: The case of the Justice and Development Party in Turkey. Party Politics, Online first September 22, 2020. https://doi.org/10.1177/1354068820960010 